\title{
ע Suomen passiivin ja impersonaalin määritelmistä ja keskinäisistä suhteista
}

\author{
TAPANi KelomäKI
}

Passiivi on vanha mutta elinvoimainen käsite eri kielioppiperinteissä. Kielten kuvauksissa sille on annettu selvästi toisistaan poikkeavia sisältöjä. Laajasta yleislingvistisestä passiivia käsittelevästä kirjallisuudesta sille voi pelkistää kaksi päämerkitystä: Toisaalta passiiviksi kutsutaan rakenteita, joissa lauseen informaatiorakenne on käänteinen aktiivilauseeseen verrattuna. Teon kohde on etualaistettu lauseenalkuiseksi teemaksi, ja tekijä jää taka-alalle ja on verbin jäljessä; sanajärjestys on siis päinvastainen aktiivilauseeseen verrattuna. Esimerkiksi englannin passiivi on etualaistava:

(1) Bill was hit by John. (Vrt. John hit Bill.)

Toisaalta passiiveiksi sanotaan persoonaa häivyttäviä eli referenssiltään avoimia rakenteita. Tällainen on suomen passiivi, joka on kyllä persoonainen, mutta tekijän persoona on häivytetty. Ei siis osata tai haluta sanoa, kenestä on kysymys:

(2) Ähtärissä riideltiin taksijonossa.

Aiemmassa tutkimuskirjallisuudessa persoonaa häivyttävistä rakenteista käytetään melko yleisesti myös nimitystä impersonaali. Passiivia koskeva käsitteistö on tutkimusperinne- ja kielikohtaisuudessaan varsin moninaista, ja niinpä esimerkiksi passiivia on pidetty impersonaalin alalajina ja päinvastoin.

Verbin passiivimuoto sisältää passiivimorfeemin, kuten suomessa -ta-morfeemin sanassa kerrotaan (ks. ISK $2004 \$ 110$ ), tai on perifrastinen kuten englannissa. Passiivimorfeemi on kielten kuvauksissa passiiviksi katsottujen rakenteiden keskeinen aines. Toisaalta passiiveina on pidetty myös aktiiviverbillisiä rakenteita. Tällaisia ovat esimerkiksi suomen kielen rakenteet, joita on kutsuttu monipersoonaisiksi passiiveiksi (jouduin sateen yllättämäksi, asiat järjestyvät, ks. lukua 6). 
Persoonan häivytys ei ole yksinomaan muodollisesti passiivisten ilmausten ominaisuus, vaan impersonaalin tehtävää ilmaistaan kielissä monenlaisilla keinoilla. Persoonan voi häivyttää esimerkiksi suomen passiivin kaltaisella passiivilla, nollapersoonalauseella ja yksikön 2. persoonan avoimella käytöllä; germaanisisissa kielissä käytetään vastaavassa funktiossa man-passiivia ja eräissä romaanisissa kielissä refleksiivirakenteita. Toisaalta objektin etualaistamiseen ei välttämättä tarvita passiivia, vaan, kuten suomessa, objekti voidaan myös aktiivilauseessa etualaistaa pelkästään sanajärjestyksen keinoin siirtämällä se lauseen alkuun ilman muita morfosyntaktisia muutoksia - siis muuttamatta verbiä passiivimuotoon.

Käytännössä passiivin määritelmät ja analyysit ovat aina monitasoisia. Passiivilla tarkoitetaan lauseita tai rakenteita, joilla on sekä passiivin muodollisia että semanttisia ominaisuuksia. Pragmatiikkakin on määritelmissä mukana, sillä etulaistavan passiivin motivaatio on objektin tematisointi, joka on sidoksissa kontekstiin. Myös persoonan häivytyksen syyt ovat pragmaattisia. Kyse voi olla esimerkiksi lauseen tekijän yhdentekevyydestä tai anonyymisyyden suojelusta tai dialogissa suoran puhuttelun välttelystä (ks. alalukua 4.1).

Kirjoitukseni on käsiteanalyysia suomen monenlaisista passiiveiksi nimetyistä rakenteista. Etsin systematiikkaa fennistiikan passiivikäsitysten kentästä ja tarkastelen erilaisia passiivikäsityksiä ja passiivimaisia ilmauksia. Käyn myös läpi näiden ilmausten passiiviominaisuuksia esimerkiksi pohtien kohta kohdalta, ovatko monipersoonaiset passiivit ja niiden kaltaiset rakenteet passiivisia etualaistavassa vai persoonaa häivyttävässä mielessä. Tarkasteluun liittyy olennaisesti rinnastuksia muihin impersonaaliilmauksiin, sillä kuten luvun 2 katsauksesta käy ilmi, monet yleislingvistit pitävät esimerkiksi aktiiviverbin sisältäviä nollapersoonalauseita passiivisina. Kirjoituksessa esittämäni esimerkit on poimittu tarkastelemistani tutkimuksista, ovat niiden muunnelmia tai itse tuottamiani lauseita vastaesimerkeiksi tai argumentaation havainnollistamiseksi.

Tarkastelen myös passiivikäsitteiden historiaa, sillä fennistiikassa passiivin käsitteelliset jatkumot ovat pitkiä. Jo Setälän ajoista lähtien on ajateltu, että suomessa ei varsinaista passiivia ole, mutta silti suomen impersonaalista passiivia sanotaan yhä passiiviksi. Passiiveina on esitelty myös rakenteita (esim. monipersoonaiset passiivit), joista monet on tunnettu aiemmin muilla nimillä. Käsitehistoriallisesti huomionarvoista on lisäksi etualaistavan passiivin mallin jatkuva vaikutus kuvauksiin.

Ensimmäinen luku esittelee lingvistiikan moninaisia passiivikäsityksiä. Toinen, impersonaaleja kuvaava luku näyttää, että myös niistä on useanlaisia käsityksiä, vaikka niitä yhdistääkin avoin persoonareferenssi. Kolmas luku käsittelee fennistiikan passiivikäsityksiä ja niiden historiaa. Tuon siinä esiin, ettei käsitys passiivista ole yhtenäinen ja että monesti lähes samaan käsitteeseen on viitattu useilla eri termeillä. Esimerkiksi Ison suomen kieliopin (2004) laaja esitys passiiveista käsittää keskenään melko erilaisia rakenteita. Neljäs luku tarkastelee suomen passiivin harmaita reuna-alueita. Näillä alueilla passiivimuotoisella ilmauksella on aktiivinen semantiikka, jolloin persoonaviittaus on spesifi. Viides luku esittelee aktiivilauseita, jotka toteuttavat persoonan häivyttämisen (tai yleistämisen) funktiota. Erityisesti passiiviin vertautuu nollapersoonalause, jolloin käy ilmeiseksi, että suomen passiivi ja nollapersoona toteuttavat samaa semanttista tehtävää toisiaan täydentäen. Kuudes luku käsittelee monipersoonaisia passiiveja. Niissä 
objekti on etualaistettu, mutta verbi voi olla aktiivinen ja persoonaviittaukset spesifejä. Monipersoonaisten passiivien tarkastelu osoittaa etualaistamisen ja impersonaalisuuden erilaiset vaatimukset lauseen rakenteelle; toisaalta se paljastaa passiivitutkimuksen sitkeitä ristiriitaisuuksia. Seitsemäs luku pohtii etualaistusta yleisemmin kuin pelkästään passiivin kannalta. Suomessa sanajärjestyksen muuntelu sallii lauseen teemapaikalle etualaistettavan monenlaisia lausekkeita eikä siihen tarvita etualaistavan passiivin kaltaisia rakenteita. Lopuksi luvussa kahdeksan ehdotan jo tiedossa olevien seikkojen kokoamista ja uudelleen ryhmittämistä.

\section{Passiivin määritelmiä}

Tässä luvussa esittelen ja erittelen erilaisia määritelmiä, joita passiiville on annettu lingvistiikassa. Niitä on aihetta käsittelevässä runsaslukuisessa tutkimuskirjallisuudessa monia ja monenlaisia. Seuraavassa luvussa käsittelen puolestaan impersonaalin määrittelyä. Jako erillisiin lukuihin pelkistää etualaistuksen ja impersonaalisuuden eroja sekä selventää sitä, että passiiveja ja impersonaaleja voidaan tutkia monista eri näkökulmista. Nämä näkökulmat eivät useinkaan ole tutkimuksissa selvästi näkyvissä.

Aluksi esitän tiivistelmän passiivin määritelmien merkittävimmistä ominaisuuksista (asetelma 1).

\section{Asetelma 1.}

Passiivin ominaisuuksia.

1. Syntaktisesti passiivi etualaistaa (promotoi) objektin, siirtää sen subjektin paikalle verbin eteen, jolloin objektista tulee subjekti. Verbi on passiivimuodossa, ja aktiivilauseen agenttisubjekti demotoituu, eli se joko poistuu tai menettää alkuasemaisuutensa ja saa obliikvisen sijamerkinnän. Tämä on niin sanottu prototyyppinen passiivi, esimerkiksi Bill was hit by John. Lauseen tekijä on reemassa prepositiolausekkeena, joka vastaa obliikvista substantiivilauseketta.

2. Passiivi on useimmiten aktiiviin verrattuna morfologisesti ja morfosyntaktisesti tunnusmerkkinen. Sillä on omia morfeemejaan, jotka ovat eri kielissä erilaisia, ja passiivilauseiden rakenteet ovat aktiivilauseiden rakenteita mutkikkaampia. Teksteissä passiivi on aktiivia harvinaisempi ja käyttökonteksteiltaan rajallisempi.

3. Passiivin semantiikka ja pragmatiikka on monitahoista. Passiivi paitsi etualaistaa patientin ${ }^{1}$ verbin eteen teemapaikalle lauseen puheenaiheeksi myös häivyttää tai poistaa tekijän. Vuorovaikutuksellisesti passiivilla on monia tehtäviä. Se on esimerkiksi keino osoittaa suhdetta puhuteltuun, sillä passiivi-

\footnotetext{
1. Patientti on semanttinen rooli, joka kuvaa toiminnan kohdetta. Yleisimmin patientin rooli on lauseessa objektilla. 
rakenteita käytetään usein suoran persoonaviittauksen välttämiseen muodollisissa puhutteluissa.

Kuten asetelmasta 1 näkyy, määritelmät käsittävät sekä muodollisia että semanttisia ja pragmaattisia ominaisuuksia. Passiivi kuvataan rakenteellisesti ja sen funktio patientin etualaistavana tai tekijän häivyttävänä rakenteena mainitaan. Passiivirakenteilla on harmaa alueensa, sillä niillä on aktiivista semantiikkaa ja vastaavasti aktiivisen verbinmuodon sisältävillä lauseilla on passiivista semantiikkaa, kuten luvuista 4-5 käy ilmi.

Merkittävä osa passiivikäsitysten eroavaisuuksista liittyy passiivin syntaksiin, erityisesti transitiivisuuden ja passiivin suhteeseen (ks. esim. Shibatani toim. 1988). Tällöin on pelkistetysti sanoen kysymys siitä, voiko intransitiivilause olla passiivissa, kun siinä ei ole etualaistettavaa objektia. Blevins (2003: 475-488, 507-508) edustaa jyrkkää kantaa, jonka mukaan vain prototyyppinen etualaistava passiivi on passiivi. Siksi vain transitiivilauseet voi "muuntaa" passiiveiksi. Shibatanikin (1985: 821-822, 837; 2006: 220) puhuu passiiveista lähinnä tuollaisina rakenteina korostaen transitiivisuuden ja passiivin keskinäistä riippuvuutta. Hänen mukaansa prototyyppisten passiivien lisäksi on kuitenkin muitakin passiiveja (esim. refleksiiviverbillisiä ja monenlaisia nominatiivisubjektittomia lauseita), joita yhdistää lauseenalkuisen subjektin patienttius ja semanttisesti passiivin keskeinen tehtävä, agentin demootio (defocusing; Shibatani 1985: 830-837, 840-845). Shibatanille passiivi on yläkäsite, joka kattaa joukon hyvin erilaisia tapauksia.

Myös seuraavaksi esittelemieni tutkijoiden passiivikäsitykset ovat samaan tapaan sekakoosteisia, mistä seuraa, että niiden alaan kuuluu erilaisia rakenteita. Foleyn ja van Valinin (1985) näkemys passiivista muistuttaa Shibatanin käsitystä. Heidän mukaansa prototyyppisestä passiivista poikkeavat passiivit ovat funktionaalisia (mas. 306). Se tarkoittaa tekijäsubjektin häivyttämistä. Muodollisesti nämä passiivit ovat sekalainen ryhmä rakenteita; niihin kuuluvat esimerkiksi one-, man- ja monet refleksiiviset rakenteet. Näin ajatellen suomen nollapersoonakin on luettavissa passiivikäsitteiden alaan. Foley ja van Valin (mas. 299-334) myös esittävät, että passiivi on demotionaalinen, jos se vain poistaa tekijäsubjektin, ja promotionaalinen, jos se etualaistaa subjektiksi jonkin aktiivilauseen elementin, lähinnä objektin. Tässä luokittelussa suomen passiivi on siis demotionaalinen (ks. mas. 322).

Siewierskallekaan (2005: 434-437) ei asetelman 1 ensimmäinen ominaisuus eli etualaistaminen ole välttämätön. Niinpä myös suomen passiivi on hänen luokittelussaan passiivi, koska verbissä on passiivin tunnus, rakenne kontrastoituu aktiiviin ja lauseen persoonaviittaus on avoin. Tällaisella kannalla ovat myös Helasvuo ja Vilkuna (2008: 228-229). Comriekin (1977) argumentoi sen puolesta, että subjektin häivyttäminen ja objektin etualaistus ovat toisistaan riippumattomia. Objektista riippumatonta subjektia häivyttävää rakennetta hän kutsuu impersonaaliseksi passiiviksi mainiten esimerkkinä nimenomaan suomen (mts. 49-50). Tällainen passiivikäsitys on hyvin etäällä edellä mainitsemastani Blevinsin edustamasta transitiivisuuteen sidotusta objektin etualaistavasta käsityksestä.

Passiivia on tarkasteltu myös funktionaalisen universaalin näkökulmasta, jolloin on painotettu passiivilauseen subjektin patienttiutta sekä lauseessa olevaa etualaistusta 
diskurssifunktion kannalta (esim. Shibatani 1985; Kittilä 2000). Kittilän (mas. 288-291) mukaan maailman kielten passiiveille ei ole löydettävissä yhtä yhteistä rakennepiirrettä, mutta agentin demootio on funktionaalisesti hyvin yleistä.

Kuten on ilmennyt, passiivin määritelmissä on melkoisesti vaihtelua. Tämä näkyy myös niissä lukemattomissa kirjoituksissa, joihin mainitsemissani lähteissä viitataan. Prototyyppisen etualaistavan passiivikäsityksen ja erilaisten persoonaa häivyttävien passiivikäsitysten välillä on laaja harmaa alue, jolle tulee jatkuvasti uusia ehdotuksia. Niiden todellista uutuutta on vaikea välittömästi huomata. Vika ei ole tutkijoissa vaan asian vaikeudessa, sillä se, miten etualaistaminen ja tekijän häivyttäminen kaikkine pragmaattisine vivahteineen ilmenee erirakenteisissa kielissä, on mutkikas kokonaisuus.

\section{Impersonaali}

Yleistäen voi sanoa, että tutkimuskirjallisuudessa impersonaali on lause tai muu rakenne, jonka keskeinen piirre on agentin avoin persoonareferenssi. Etualaistavaan passiiviin verrattuna impersonaali on jossain suhteessa vajaa. Se voi esimerkiksi olla subjektiton, tai objekti voi säilyä etualaistumatta. Rakenteen pääkäyttö on tekijän tai tekijyyden hämärtäminen. Näin ajattelevat muiden muassa Blevins (2003: 473-476, 482, 507-508) ja Shibatani (2006).

Siewierskalle (2008) impersonaali on laaja yläkäsite eri kielissä ja kieliopeissa esiintyville subjektiltaan vajaille konstruktioille. Vajavaisuus voi olla morfosyntaktista ja semanttis-pragmaattista, mikä tarkoittaa eriasteista puutteellisuutta subjektiargumentin spesifisyydessä ja morfosyntaksissa. Tämä kattaa muun muassa geneeriset, muodolliset, puuttuvat ja epäagentiiviset subjektit. Siewierskan tarkoittamia vajaita konstruktioita ovat esimerkiksi modaaliset lausekontekstit, eksistentiaalilauseet ja säälauseet.

Passiivia pidetään monesti yhtenä impersonaalien lajina (Helasvuo \& Vilkuna 2008; yleisemmin Siewierska 2008; virosta ks. alav. 6). Shibatani (1985: 821) taas luokittelee refleksiivit ja muut impersonaalit pseudopassiiveiksi. Molempia kantoja perustellaan subjektin tekijyyden jonkinlaisella puutteellisuudella, esimerkiksi patienttiudella tai kieliopillisen subjektin poikkeuksellisuudella, kuten sen sijainnilla muussa paikassa kuin lauseen alussa (ks. mas. 837-838; Kittilä 2000).

Helasvuo ja Vilkuna (2008) tarkastelevat impersonaaleja morfosyntaktisten ja semanttisten piirteiden kannalta. He pohtivat erityisesti patienttisubjekteja ja muuten subjektiltaan vajaita lauseita. Impersonaalisilla rakenteilla on heidän mukaansa seuraavia ominaisuuksia (mas. 219-220):

Asetelma 2.

Impersonaalien ominaisuuksia.

1. Yksipersoonaisuus. Se tarkoittaa verbin taipumattomuutta (esim. modaaliverbien yhteydessä), subjektin aitoa puutetta (esim. tilalauseissa) tai yksipersoonaista passiivia.

2. Agentin puute (esim. kokijalauseissa ja eksistentiaalilauseissa). 
3. Ykkösargumentin (so. verbin keskeisimmän argumentin, yleensä subjektin) obliikvisuus (esim. omistusrakenteessa).

4. Ykkösargumentin epäspesifisyys (avoin referenssi).

Helasvuo ja Vilkuna (2008: 226-230) näyttävät, miten suomen impersonaalisten konstruktioiden persoonaviittaus on eri syistä avoin ja miten syntaktisesti yksipersoonaiset konstruktiot, esimerkiksi omistusrakenne ja modaalikonstruktiot, erottuvat passiivista ja nollapersoonasta. Artikkelista käy myös ilmi, että passiivia ja nollapersoonaa yhdistää samantapainen avoin persoonaviittaus.

Kuten näkyy, impersonaali kattaa monenlaisia ilmiöitä ja sen suhde passiiviin on usein päällekkäinen. Blevins, Siewierska ja Shibatani sekä Helasvuo ja Vilkuna määrittävät impersonaalin yleisesti mutta mahdollisimman täsmällisesti. Määritelmistä näkyy, miten impersonaalinen käsite on riippuvainen valitusta näkökulmasta, erityisesti suhteessa passiiviin. Myös syntaksin ja semantiikan painotukset näkyvät määritelmissä. Tässä kirjoituksessa tarkastelen impersonaaleina ilmiöitä, joissa tekijän persoonareferenssi on avoin, siis tekijää häivyttävä.

\section{Suomen passiivikäsitysten vertailua}

Tässä luvussa esittelen fennistiikan passiivitutkimusta. Etsin siitä käsitteellisiä jatkumoita sekä pohdin terminologisia ongelmia ja muiden kielten kuvausten vaikutusta suomen passiivin kuvaukseen. Tarkastelu etenee kronologisesti.

Suomen passiivin tutkimuksessa morfosyntaktinen näkökulma on ollut hallitseva, mistä on seurannut kohtalainen yksimielisyys siitä, mitkä rakenteet ovat passiiveja. Kuitenkin myös passiivin semanttiset ominaisuudet ovat olleet tiedossa ainakin jo 180o-luvun alkupuolella ja etenkin persoonanhäivytys on ollut jo pitkään esillä sen kuvauksissa. Passiivin persoonanhäivytystä on myös vertailtu muihin persoonareferenssiltään avoimiin ilmauksiin, esimerkiksi nollapersoonalauseeseen. Sittemmin passiiveiksi on katsottu sellaisiakin rakenteita, joita ei ole aiemmin pidetty passiiveina (ks. lukua 6).

Keskeisimmät havainnot ja päätelmät suomen passiivin luonteesta ja eroista muiden kielten passiiveihin on tehty varhain. Pääkkönen (1994: 67-68) mainitsee, että Keckman piti jo vuonna 1829 passiivia "persoonattomana päluokkana" ja "pikemminkin jonkinlaisena impersonaalisena taivutusluokkana eikä indoeurooppalaisten kielten passiivien suoranaisena vastineena”. Lisäksi Keckman katsoi, että muiden kielten persoonaista passiivia vastaavat usein suomen kielen aktiiviset refleksiiviverbit (Pääkkönen mp.).

Fennistiikan syntaksin kasautuva perinne palautuu Setälän teoksiin. ${ }^{2}$ Hän toteaa Lause-oppinsa ensimmäisessä painoksessa $(1880 § 50)$ seuraavasti:

2. Setälän lähteeksi on mainittava Jahnssonin teos (1871), jossa luetellaan useimmat suomen passiivin perusominaisuudet: suomessa ei ole ruotsin passiivin kaltaista passiivia, aktiivilauseen objektia ei vastaa passiivilauseen subjekti, intransitiiviverbeilläkin on passiivimuoto, suomen passiivi on impersonaalinen, ja sen paras vastine ruotsissa on man-rakenne, jota tosin voi pitää nollapersoonalauseenkin vastineena (mts. 3). 
- - impersonaalia 1. passiivia käytetään, kun toimittavaa persoonaa, subjektia ei mainita; esim. Käyden kylään päästään, juosten tielle jäädään.

Lisäksi Setälä mainitsee ( $1880 \$ 50)$ passiivin käytön monikon ensimmäisenä persoonana ja antaa esimerkin passiivista suostuttelevassa käytössä (vrt. ns. lääkäripassiiviin alaluvussa 4.1): "Poika otti äijän mukaansa - no, kuljetaan vähän matkaa yhtenä, ja istutaan sitten lepäämään kivelle." Samassa yhteydessä (mp., 2. muistutus) hän toteaa, että "persoonattomasti käytetään myös yksikön kolmatta ja toista persoonaa: Sen kohta kuulee, että hänessä on älyä."

Lause-oppinsa kolmannessa laitoksessa Setälä (1891 $\$ 93,1$. muistutus) toteaa suomen passiivin olevan erilainen kuin indoeurooppalaisten kielten passiivit. Hän kytkee passiivin tiukasti transitiivisuuteen (mp., 2. muistutus):

Todellinen passiivinen merkitys, muiden kielten tapaan, saattaa olla vain transitiiviverbin passiivin partisiipilla. Esim. Kirjat ovat luetut. Kirja on luettavana.

Tämä ajatus edeltää Helasvuon (2006) kopulapassiivia, viron seisundipassiivia (Erelt, Viks, Erelt, Kasik, Metslang, Rajandi, Ross, Saari, Tael \& Vare 1993: 30; ks. alav. 6) ja Iso suomen kieliopin (2004 $\$ 1335)$ tilapassiivia. Palaan näihin lähemmin alaluvussa 6.2.

Lisäksi Setälä (mp.) esittää havainnon (automatiivi)johdosten ja passiivin merkitysten läheisyydestä:

- - muiden kielten persoonallista passiivia suomessa usein vastaa myös un, ynloppuinen verbi eri merkitysten vivahduksella, esim. Minä pelastuin (vrt. minut pelastettiin) - joku määräämätön henkilö pelasti minut.

Tässä on hahmollaan ISK:n (2004 $\$ 1344-1346)$ johdospassiivi (ks. alalukua 6.3).

Passiivin perusominaisuuksien lisäksi siis jo Setälä havaitsi seikkoja, joihin vasta viime aikoina on alettu kiinnittää tarkempaa huomiota, kuten passiivin käyttö direktiivisissä tehtävissä. Hän käsittelee impersonaaliseksi käsittämäänsä passiivia, mainitsematonta subjektia (nollapersoonaa) ja esimerkiksi 2. persoonan avoimen käytön tapaista käyttöä saman ilmiön rinnakkaisesiintyminä. Myöhemmin hänen kielioppiperinteessään on tapahtunut käänne. Setälän, Niemisen ja Ojajärven (1974: 86) määritelmä on nimittäin morfologisperustainen, vaikka se sisältääkin semanttisen luonnehdinnan:

Suomen kielen verbintaivutuksessa on kaksi pääluokkaa - - passiivi, yksipersoonainen pääluokka, jonka ominaisuutena on, että toimittava persoona on epämääräinen. Persoonamuotoja on vain yksi.

3. Setälä ei julkaissut uutta kielioppia. Muitakaan kokonaisia tieteellisiä kielioppeja ei ilmestynyt ennen Penttilän Suomen kielioppia (1957), joka sekään ei saanut tunnustettua asemaa pitkään aikaan. Setälän kuoltua vuonna 1935 hänen kielioppiperinteensä eli uusissa, Suomen kielen lause-oppiin (1880) perustuneissa, vähin erin muokkautuneissa koulukielioppiversioissa, kuten Setälän, Niemisen ja Ojajärven kieliopissa (1974). 
Myös Penttilä nimittää (1963: 213) passiivia verbinmuotojen pääluokaksi, eli passiivi on kuvattu morfologisena ilmiönä. Hän kuitenkin samalla esittelee joukon passiivin semanttisia ominaisuuksia, kuten persoonan epämääräisyyden. Lisäksi hän mainitsee kielioppiperinteen kytkökset latinaan ja sen persoonaiseen ja objektia etualaistavaan passiiviin.

Tuomikoski (1971) sen sijaan hahmottaa passiivin aseman kieliopissa uudella tavalla. Hän katsoo passiivin kuuluvan suomen kielen persoonajärjestelmään neljäntenä persoonana, koska se on persoonainen ja indefiniittisen referenssisuhteensa ansiosta erilainen kuin muut persooniin viittavat muodot. Tällaisella passiivikäsityksellä ei ole mitään yhteyttä etualaistavaan passiiviin. Runsaat kymmenen vuotta myöhemmin Shore (1986) toteaa jo aivan eksplisiittisesti, ettei suomessa ole etualaistavaa passiivia.

Vilkuna (2000: 342) määrittelee passiivin seuraavasti:

\section{Määritelmä 1.}

Yleisemmässä merkityksessä: erityinen verbirakenne, jonka yhteydessä ykkösargumentti jätetään ilmaisematta tai ehkä edustuu sellaisella epätyypillisenä tavalla kuin englannin by the Government tai suomen hallituksen toimesta. Jos objektiargumentti samalla toimii kieliopillisena subjektina, passiivia sanotaan personaaliseksi; muussa tapauksessa kyseessä on impersonaalinen passiivi.

Määritelmässä ei mainita verbin passiivimuotoisuutta, ei myöskään henkilötekijäisyyttä. Märitelmässä mikään ei estä sitä kattamasta muutakin subjektittomuutta, esimerkiksi nollapersoonalausetta. Toisaalla Vilkuna (mts. 138-140) edellyttää, että ykkösargumentti on henkilötarkoitteinen, että passiivilla vältellään henkilön spesifiä osoittamista ja että passiivilauseessa on passiivimorfeemi. Lisäksi hän mainitsee monipersoonaisen passiivin (mts. 144-146); siihen palaan luvussa 6.

$\mathrm{VISK}^{4}$ (s.v. passiivi) määrittelee passiivin rakenteeksi seuraavalla tavalla:

\section{Määritelmä 2.}

Passiivi on rakenne, jossa verbinmuodolla, esim. sanotaan, puhuttiin, ei tehty, olisi vastattu, esitetään tilanne ilmaisematta tekijää tai muutakaan subjektia, esim. Suomessa juodaan paljon, Keitä juhliin vielä odotettiin? Tällaista passiivia sanotaan yksipersoonaiseksi, sillä se ei vaihtele persoonan mukaan. Se kuuluu persoonajärjestelmään ensimmäisen, toisen ja kolmannen persoonan ohella ja on siis osa verbintaivutusta.

Määritelmässä verbin passiivimuotoisuus on rakenteen passiivisuuden välttämätön ehto. Siihen liittyy erottamattomasti persoonaa häivyttävä funktio; toisaalta nostetaan esiin se, että passiivi kuuluu verbintaivutukseen. VISK (mp.) antaa passiiville myös laajan määritelmän:

4. VISK viittaa Ison suomen kieliopin (2004) verkkoversion Määritelmät-osioon. Olen käyttänyt siellä olevia määritelmiä ISK:n määritelmien vertailukohteena tai silloin, kun ISK:sta puuttuu käsitteen täsmällinen määritelmä. 


\begin{abstract}
Määritelmä 3.
Laajemmassa mielessä passiiviksi kutsutaan rakenteita, joissa verbin muodolla osoitetaan tekijän jäävän taka-alalle. Tällöin passiivi voi olla myös monipersoonainen eli verbin muoto voi vaihdella persoonan mukaan. Lauseessa on subjekti, joka merkityksen kannalta kuitenkin vastaa objektia. Suomessa tällaisia ovat muutospassiivi (tyttö tuli valituksi, tytöt tulivat valituiksi), tilapassiivi (tapaus on poliisin tutkittavana, tapaukset ovat poliisin tutkittavina) ja johdospassiivi (asia järjestyy, asiat järjestyvät).
\end{abstract}

Tässä määritelmässä verbiltä ei edellytetä passiivimuotoa, joskin tekijän sanotaan jäävän taka-alalle juuri verbin muodon takia. Laaja määritelmä ei ole suppean laajennus, vaan näillä kahdella määritelmällä - kuten Vilkunankin (2000) määritelmillä - on eri perustat, sillä suppea on impersonaalinen ja laaja lähinnä etualaistava.

Taustoittavassa kappaleessa Iso suomen kielioppi (2004\$1313) käsittelee suomen passiivia laajasti ja esittelee passiivien monenlaista kieltenvälistä vaihtelua; myös passiivin universaalin määrittelyn vaikeus todetaan. ISK käyttää passiivin määrittelyssä asetelmassa 1 (s. 112-113) mainitsemiani kriteereitä ja tuo esiin edeltäjiensä tapaan, että suomessa on useita erilaisia passiivirakenteita eikä siinä juuri esiinny prototyyppistä passiivia.

ISK (2004 §1313) määrittelee passiivin seuraavasti:

\title{
Määritelmä 4.
}

Passiivilla tarkoitetaan yleisesti ottaen lauseita, joissa verbin muoto tai predikaatin rakenne osoittaa lauseen ydinjäsenten edustuvan toisin kuin tavallisesti aktiivilauseessa: subjekti jää taka-alalle, ja vastaavasti jokin muu lauseenjäsen voi saada joitakin subjektin piirteitä. Suomessa on useita passiivin luonteisia rakenteita, joista yleisin ja monikäyttöisin on yksipersoonainen passiivi. Yksipersoonaisessa passiivilauseessa ei ole ilmisubjektia, ja sen finiittiverbi on passiivimuodossa. Passiivimuotoa sanotaan yksipersoonaiseksi, koska se ei vaihtele eri persoonissa.

\section{- - Huomattakoon, ettei asiaa liene vielä päätetty.}

Tämän mukaan passiivi on lause (VISK:n määritelmässä rakenne; ks. Määritelmä 2 edellä), jonka verbissä on jotain morfosyntaktisesti passiivista, objekti on yleisimmin verbin edellä eikä tekijään viitata spesifisesti. Subjektin jääminen taka-alalle tarkoittanee poissaoloa, sen väistymistä lauseen alusta reemaan tai avointa referenssiä. Tämä kattavuutta tavoitteleva määritelmä on erittäin tulkinnanvarainen ja rajoiltaan sumea.

Helasvuo (2006) kehittää Tuomikosken ajatusta neljännestä persoonasta edelleen. Hänen mukaansa passiivin avulla kuvataan puhetilanteen osanottajarooleja, sillä se indeksoi persoonan, jonka avoin referenssisuhde täytyy päätellä kontekstista. Helasvuo katsoo (mas. 236), että suomessa on kaksi passiivia, yksinkertainen (yksipersoonainen) passiivi (Hilkka viedään vietiin oltiin viety sairaalaan) ja kopulapassiivi olla + partisiippi (adjective type; esim. Hilkka on viety sairaalaan). Hän ei liitä passiivikäsitteisiinsä eksplisiittisesti prototyyppisen passiivin syntaktisia ominaisuuksia mutta sanoo passiivilauseiden muistuttavan prototyyppiä. Edeltäjiensä tavoin Helasvuo (mp.) kuvaa passiivi- 
lauseen patientin objektiksi, koska se ei kongruoi verbin kanssa ja se voi olla akkusatiivissa (Minut oli viety sairaalaan).

Helasvuo (2006: 243-245) toteaa kopulapassiivilauseen ja predikatiivilauseen samankaltaisuuden ja huomauttaa, että yksinkertainen passiivi kuvaa toimintaa ja kopulapassiivi toiminnan tulosta, ${ }^{5}$ mihin vaikuttaa myös preesensin irresultatiivinen prosessuaalisuus ja imperfektin statiivinen tilamaisuus. Larjavaara (2007) huomauttaa Helasvuon analyysiin, että pöytä on kauniisti maalattu -tyyppisissä lauseissa on passiivipredikatiivi eivätkä lauseet ole aitoja passiivilauseita, sillä niiden semantiikka on passiivista riippumatonta luonnehtivan lauseen semantiikkaa. Hän korostaa, että analyysissa on otettava huomioon lausetyyppi, pääluokka ja tempus, joten olla-verbin passiivilla ei ole omaa semantiikkaa, koska sama semantiikka on vastaavilla aktiivimuodoillakin (vrt. puu on kaatunut puu on kaadettu). Epäilemättä asia on näin, mutta tässä tapauksessa refleksiivijohdin vielä mutkistaa tilannetta. Palaan asiaan johdospassiivin yhteydessä (ks. alalukua 6.3).

Tiivistäen voi sanoa, että fennistiikan tutkimusperinteessä (yksipersoonainen) passiivi on käsitetty impersonaaliseksi ja nähty sen erot prototyyppiseen passiiviin, jota suomessa ei yleensä katsota olevan. Laajat määritelmät (etenkin 1 ja 3) pyrkivät kuitenkin kattamaan sekä etualaistuksen että impersonaalisuuden, mistä syystä ne jäävät epäselviksi. Passiivi-termi on fennistiikassa edelleen käytössä, ja Iso suomen kielioppi (2004 $\$ 1331)$ perustelee termin käyttöä seuraavasti:

- - käytetään fennistisen perinteen mukaista nimitystä passiivi, koska rakenteella on kuitenkin olennaisia passiivin ominaisuuksia ja koska monilla ehdotetuilla vaihtoehtoisilla nimityksillä on muuta vakiintunutta käyttöä.

Jatkuvasti on kuitenkin myös esitetty muita nimityksiä. Jo Setälä ja myöhemmin esimerkiksi Nuutinen (1981: 23) ja Vilkuna (2000: 144) ovat ehdottaneet, että suomen passiivia voisi kutsua - erotukseksi etualaistavasta passiivista - impersonaaliksi ${ }^{6}$; sen nimeksi on tarjottu myös indefiniittiä (ks. Shore 1986: 14-16). Myös Blevins (2003: 482-488) pitää impersonaalia sopivana nimityksenä suomen passiiville ja korostaa erityisesti sitä, ettei aktiivilauseen objekti muunnu passiivilauseen subjektiksi. Helasvuo ja Vilkuna (2008) taas kritisoivat impersonaalia, koska se viittaa henkilöttömyyteen. Palaan termiongelmiin etualaistuksen yhteydessä luvussa 7 .

Toinen huomio fennistiikan passiivitutkimuksesta on tietty hajanaisuus. Kuten edellä on ilmennyt, tutkimusta on tehty ottamatta huomioon edeltävien tutkijoiden tuloksia. Esimerkiksi Setälän (1891 \$93, 2. muistutus) "todellinen passiivinen merkitys" (ks. lukua 3), Ison suomen kieliopin (2004 $\$ 1335)$ tilapassiivi (ks. alalukua 6.2) ja Helasvuon (2006) kopulapassiivi ovat lähikäsitteitä, mikä ei kyseisistä tutkimuksista aina käy ilmi.

5. Shibatanin (1985: 841) mukaan kielissä on yleistä, että kopulapassiivi on statiivinen, siis tilamainen.

6. Viron passiivia nimitetään usein impersonaaliksi (ks. Erelt ym. 1993: 30; ks. kootusti myös Jokela 2012: 50). Erelt ym. (mp.) määrittelevät, että jos lauseen tekijäsubjekti on myös kieliopillinen subjekti, on lause aktiivilause; muuten se on passiivilause. Muutoin he ovat sitä mieltä, että viron -kse-passiivi ja nollapersoona ovat impersonaaleja (mts. 30-31, 227-228). Ei-impersonaalinen passiivi on lähinnä niin sanottu seisundipassiiv: ta on üllatatud (mts. 30). 


\section{Aktiivisia passiiveja}

Kuten edellä on ilmennyt, suomen passiivi käsitetään yleensä epäspesifisesti henkilötekijäiseksi. Tässä luvussa esittelen muutamia tunnettuja tapauksia, joissa passiivimorfeemin sisältävän rakenteen persoonaviittaus on pragmaattisista syistä spesifinen. Passiivimuotoinen verbi on siis semantiikaltaan aktiivinen.

\subsection{Finiittisiä aktiivisia passiiveja}

Tarkastelen ensin tapauksia, joissa passiivilause ei ole impersonaalinen, koska tiedetään, kenestä on kysymys. Näin on esimerkiksi silloin, kun puhutussa nykysuomessa käytetään verbin passiivimuotoa monikon 1. persoonan muotona: me tullaan ihan kohta. Passiivia käytetään myös direktiivinä, kun puhuja ja puhuteltu kuuluvat samaan joukkoon: tehdään se nyt. Laurannon (2015: 43-46) termi rakenteelle on inklusivinen imperatiivi. Näiden lisäksi voidaan erottaa rakenne, jota ei-kielitieteilijät kutsuvat yleisesti lääkäripassiiviksi, joka on näennäisesti inklusiivinen imperatiivi, koska lääkäri ei osallistu potilaan toimintaan, mutta passiivilla hän luo yhteisyyden tunnelmaa: käydäänpä nyt siihen selälleen (Shore 1986: 42; Sorjonen 2001: 91-92). Shibatani (1985) antaa esimerkkejä samantapaisesta passiivin käytöstä useista eri kielistä. Suomessa passiivilla on myös muuta direktiivistä käyttöä: hajaannutaan, lähdetäänpäs siitä nyt jo lätkimään 'hajaantukaa, häipykää.

Oma tyyppinsä on myös dialoginen passiivi (ks. Makkonen-Craig 2005: 65-66, 225-226), jolla tekstin kirjoittaja vetoaa lukijaan, jotta tämä miettisi tekstissä kuvattua asiaa, ja toisaalta kirjoittaa itsensä tekstiin välttäen eksplisiittisen viittauksen itseensä hieman samaan tapaan kuin on mahdollista tehdä nollapersoonalla. Makkonen-Craig (mts. 84) näyttää, miten kehitysyhteistyötä pohdiskelevassa artikkelissa toimittaja pohjustaa haastateltavan kommenttia passiivilauseella (ennen kuin kysytään Harri Holkerilta), jolloin artikkelin lukijakin tulee haastattelun osalliseksi.

Passiivin aktiivisessa käytössä (paitsi monikon 1. persoonaan viittaavana) tekijää ei siis häivytetä, vaan sillä vältetään suora viittaus lukijaan tai puhuteltuun. Perehtymättä tähän passiivin vuorovaikutukselliseen tehtävään tässä yhteydessä enempää voi todeta, että kysymyksessä ei ole aidosti avoin vaan spesifi persoonaviittaus. Esimerkiksi niin sanotulla lääkäripassiivilla viitataan potilaaseen ja dialogisella lukijaan tai kuulijaan. Näin kysymyksessä on pikemminkin kierretty persoonaviittaus.

\subsection{Infiniittinen aktiivinen passiivi}

Jotta syntyy kokonaiskuva kaikista niistä suomen kielen rakenteista, joissa esiintyy passiivin morfologinen tunnus, käsittelen lyhyesti myös infiniittisiä passiivimuotoja. Näissä rakenteissa verbinmuodot esiintyvät enimmäkseen tekijää häivyttävässä merkityksessä: ymmärsimme asiasta sovitun jo eilen. Temporaalirakenteessa asia on mutkikkaampi. Rakenteen "preesensissä" passiivi häivyttää tekijän. Lauseessa kotiin tullessaan Jussi usein kompastuu infinitiivirakenteen ja hallitsevan lauseen tapahtumat ovat samanaikaisia ja infinitiivirakenteessa tulijat on häivytetty. Temporaali- 
rakenteen "perfektissä" juuri TU-partisiippi muodostaa eräänlaisen ajallisen opposition E-infinitiivin kanssa. Lauseessa kotiin tultuaan (vrt. tullessaan) Olli katseli telkkarista hömррӓä infinitiivirakenteen mainitsema tekeminen on hallitsevan rakenteen tekemistä aiempaa ja viittaus tulijaan on spesifinen partisiipin passiivisuudesta huolimatta. TU-partisiippi ei ole semantiikaltaan passiivinen, ja Iso suomen kielioppi (2004 $\$ 548)$ katsookin, että TUA-rakenne on morfologisesti passiivimuotoinen mutta käyttäytyy aktiivimuodon tavoin. Temporaalisuus - oikeastaan tapahtumien aikajärjestys - tulee ilmaistuksi vain TUA-tunnuksella. Kyseessä ei ole avoin persoonaviittaus vaan ajallinen seuraanto, samantapainen kuin esimerkiksi latinan consecutio temporum (ks. Linkomies $1933 \S 83$ ).

\section{Persoonaa häivyttäviä aktiiveja}

Kuten edellä on tullut esiin, impersonaalisen passiivin olennaisin tehtävä on tekijän häivyttäminen. Häivyttämiseen on kuitenkin muitakin keinoja, ja tässä luvussa annan esimerkkejä siitä, millaisia verbin aktiivimuodon sisältäviä konstruktioita tähän tehtävään käytetään niin suomessa kuin muissakin kielissä, ja vertaan niitä impersonaaliseen passiiviin. Erityisesti keskityn nollapersoonaan. Kuten luvuissa 2-3 kävi ilmi, useat tutkijat pitävät tällaisia konstruktioita ainakin jossain määrin passiiveina, ja siksi niitä on tarpeen tarkastella myös tässä yleiskatsauksessa.

Tarkasteltavissa konstruktioissa on geneerinen tai epäspesifi ihmisviitteinen subjekti tai subjekti puuttuu. Epäspesifï persoonaa voidaan ilmaista ensinnäkin monilla pronomineilla: kukapa sen tietää, näin voisi joku sanoa. Myös monikon 1. persoonan käyttö hämärtää persoonaviittausta silloin, kun pronomini me viittaa suureen epämääräiseen ihmisjoukkoon: emme voi ymmärtää alkuräjähdystä edeltävää aikaa. Yksikön 2. persoonan avoin käyttö puolestaan yleistää ja tarjoaa samastumista: jos sä haluut kunnon rantaloman, mene Kanarialle. Myös monikon 3. persoonalla voi häivyttää tekijää, sillä sen avulla voi tehdä epämääräisen yleistyksen: ne juo Tuborgia Grönlannissa (ks. Shore 1986; Kangasmaa-Minn 1980: 61) tai juovat Tuborgia Grönlannissa. Esimerkiksi germaanisissa kielissä on varsin suoria vastineita tällaisille impersonaalisille ilmauksille: you could say that, they drink Tuborg in Greenland. Uusituvan (2017) perusteellisessa esityksessä 2. ja 3. persoonan avoimista viittauksista rajakarjalan murteissa selviää, että viittauksissa on monenlaista idiolektaalista, alueellista ja tilanteista vaihtelua sekä vaihtelua erilaisissa modaalisissa konteksteissa. Suomalaisen (2018) mukaan arkikeskusteluissa 2. persoonan avoimia viittauksia käytetään muun muassa arvottavissa ja hypoteettisissa konteksteissa.

Suomen kielen kannalta hyvin olennainen persoonaa häivyttävä keino on nollapersoona. Nollapersoonalause on subjektiton, ja sen monipersoonainen verbi on yksikön 3. persoonassa. Viimeaikainen tutkimus (ks. kootusti Jokela 2012: 35-40) on seikkaperäisesti selvittänyt nollapersoonan tehtäviä ja sen suhdetta passiiviin. Seuraavaksi systematisoin näitä suhteita.

VISK antaa nollapersoonalle seuraavan määritelmän: 


\section{Määritelmä 5.}

Nollapersoonaksi kutsutaan ilmipanemattoman lauseenjäsenen tulkintaa silloin, kun tarkoitetaan ketä hyvänsä ihmistä, usein myös tai nimenomaan puhujaa itseään, esim. Jos myöhästyy viimeisestä junasta, joutuu seuraavaa odottamaan aamuun asti.

Lisäksi ISK:n (2004 $\$ 1347)$ mukaan "nolla on verrattavissa persoonapronomineihin: sanottu koskee vähintään puhujaa tai kuulijaa, mutta se on myös yleistys". Tällä kannalla on myös Laitinen (2006), samoin Vilkuna (2000: 340), joka toteaa, ettei nollapersoonaa voi ilmaista persoonapronominilla. Laitinen (mas. 212-218) painottaa, että nollan käyttö tarjoaa keskustelijoille mahdollisuuden empaattisesti samastua toistensa tilanteisiin.

Ison suomen kieliopin (2004 $\$ 1351)$ mukaan nollasubjekti on taipuvainen esiintymään yhdyslauseiden ehdollisissa alisteisissa lauseissa (jos-lauseissa): Kirsikin huusi vasten silmiä, jos siltä jotain yritti kysyä. Samoin se esiintyy usein konditionaalin sisältävissä kuviteltua tai oletettua tilannetta kuvaavissa kuin-lauseissa: asia ei ole niin kuin (äkkiseltään aiempien kuvausten perusteella) luulisi voisi luulla (mp.). Jokela (2012: 158-172) esittää tälle näkemykselle kvantitatiivista tukea lehtiaineistosta.

ISK:n (2004 \$1352, 1354) mukaan nollasubjekti esiintyy modaaliverbin sisältävissä mahdollisuutta, välttämättömyyttä ja kykyä ilmaisevissa lauseissa (Pääseekö Kaivarille farkuissa?) sekä pakkoa, velvollisuutta tai muuta sellaista ilmaisevissa nesessiivirakenteissa (täällä pitäisi siivota). Verbi voi olla myös havaintoverbi, kun on kysymys mahdollisuudesta (sieltä näkee Tallinnaan), tai kognitiivinen verbi (ei sitä koskaan tiedä) (mt. $\$ 1353,1363$ ).

Edelliset havainnot kooten voi todeta, että nollapersoonalauseen suosikkiympäristöjä ovat toteutumattomat ja potentiaaliset tilat, tapahtumat ja prosessit. Passiivilause taas kuvaa usein aikapaikkaisen ja toteutuneen tapahtuman tai prosessin (ISK $2004 \$ 1363$; ks. myös Löflund 1998: 62-67):

(3) Jyväskylän yliopiston sosiaaligerontologian professoriksi nimitettiin kutsusta valtiotieteen tohtori Marjatta Marin syyskuun alusta.

Tällaisessa kontekstissa nollapersoona on jopa epäkieliopillinen: * professoriksi nimitti Marjatta Marinin (ISK, mp.).

Yleisemmin passiivin tyypillinen konteksti on modaalisuudeltaan aktuaalistuva indikatiivi ja nollapersoonan modus irrealis. Jokela (2012: 38-39, 129-151) tekee lehtiaineistoon perustuvassa kvantitatiivisessa ja kontrastiivisessa tutkimuksessaan samanlaisen yleistyksen käyttäen nollapersoonan konteksteista termiä intensionaalinen konteksti. Hän myös laajentaa kuvaa nollapersoonasta suhteessa osallistujaviitteisyyteen. Esimerkiksi puheaktiverbin esiintyessä konditionaalimuotoisten modaaliverbien yhteydessä nollasubjekti on puhujaviitteinen ilmaisten toiveita, aikeita ja kokemuksia. (Mts. 113-116.) Preskriptiivisessä ja direktiivisessä modaalikontekstissa nollapersoona on useimmiten kuulijaviitteinen: taimet voi istuttaa lasitetulle parvekkeelle toukokuun aikana (mts. 117-121).

Penttilän (1963: 464) ja ISK:n (2004 \$1363) mukaan nollapersoona on yksiköllinen, passiivi monikollinen, mistä ISK antaa myös esimerkit (4a-b): 
(4) a. - Kyllä tässä kahden naisen voimin jaksetaan hienompikin lahja ostaa.

b. Nieminen - - oli kilpailun jälkeen huomattavan rauhallinen ja miehekkään asiallinen: - On se vähän niinkin, ettei tässä jaksa enää noita kamppeitakaan heitellä.

ISK:n (2004 $\$ 1363)$ mukaan passiivilausekin voi ilmaista yleistyksen. Silloin passiivi (5a) esittää asian sellaisena kuin se yleensä tapahtuu, kun taas nollapersoona (5b) kuvaa sen ketä tahansa koskevana ehtona.

(5) a. Pellavat ja villat kasvatettiin itse, itse kehrättiin ja kudottiin ja sitten vielä jaksettiin koruommella.

b. Siihen aikaan - -. Taloudellista tulosta tuli, kunhan vain jaksoi painaa riittävästi töitä.

Tällaisissakin tapauksessa passiivi on yleistys tositapahtumista ja nollapersoonalauseet kuvaavat toteutumatonta tapahtumista ja toimintaa.

Laitisen (2006: 212-213) mukaan ero yksipersoonaisen passiivin ja nollapersoonan välillä on implisiittisen tekijän semanttinen rooli. Passiivissa se on yleensä agentiivinen, mutta nollapersoonassa epäagentiivinen. Helasvuo (2006: 248) tarkentaa tätä todeten, että nollapersoonan referentti on useimmiten muutoksen patientti tai vastaanottaja, mutta passiivilla on tekijä. Jokelan (2012: 39, 129-157) mukaan edeltävistä tutkimuksista ilmenee, että keskeiset agentiiviset verbit viihtyvät passiivilauseissa, epäagentiiviset nollasubjektilauseissa ja että mentaaliset verbit ovat nollasubjektilauseissa konkreettisia verbejä yleisempiä.

Esittelemäni tutkimustulokset voi koota seuraavalla tavalla: Nollapersoona ja yksipersoonainen passiivi ovat impersonaalisia, ja niillä on erilaisia tehtäviä ja suosikkiympäristöjä. Tämäntapainen ajatus on pitkälle luettavissa Isosta suomen kieliopista (2004) ja Laitiselta (2006) sekä eteenpäin kehiteltynä Helasvuolta ja Vilkunalta (2008). Edelleen yleistäen voi todeta, että nollapersoona on yksiköllinen impersonaali, passiivi monikollinen. Lisäksi passiivi esiintyy yleisemmin modaliteetiltaan reaalisissa ympäristöissä, nollapersoona tavalla tai toisella irreaalisissa; passiivi häivyttää tekijää, nollapersoona kokijaa.

Passiivi kuuluu persoonajärjestelmään neljäntenä persoonana, ja sillä on oma persoonapäätteensä - Vn (ISK $2004 \$ 107)$. Vaikka nollapersoonalla ei ole päätettä verbin persoonataivutusparadigmassa, sillä on paikkansa persoonajärjestelmässä passiivin rinnalla avointa persoonareferenssiä ilmaisemassa. Tämäntapaisen ajatuksen voi nähdäkseni katsoa sisältyvän Isoon suomen kielioppiinkin (2004\$1349). Shibatani (1985) on löytänyt eri kielten erilaisille passiiveille samanlaisia "sivumerkityksiä", kuten monikollisuuden, potentiaalisuuden ja yleistävyyden. 


\section{Monipersoonaiset passiivit}

Edellä luvussa 3 selostin yksipersoonaisen passiivin syntaksia ja semantiikkaa. Tässä luvussa tarkastelen muita fennistiikassa passiiveiksi nimitettyjä rakenteita ja pohdin niiden ominaisuuksia etualaistamisen ja persoonan häivyttämisen keinoina. Tarkoitus on selvittää, ovatko monipersoonaiset passiivit lainkaan samassa mielessä passiiveja kuin yksipersoonainen passiivi.

VISK:n (s.v. monipersoonainen passiivi) määritelmän mukaan monipersoonaisten passiivirakenteiden verbi taipuu persoonissa. Näitä passiiveja ovat muutospassiivi (minä tulin valituksi, te tulitte valituiksi), tilapassiivi (tapaus on poliisin tutkittavana) ja johdospassiivi (asia järjestyy). Rakenteen kieliopillinen subjekti on semanttisesti verbin objektiargumentti. Vilkuna (2000: 144-146) esittää melko samanlaisia näkemyksiä muutospassiivista ja tilapassiivista. Hän ei kuitenkaan käytä niistä edellä mainittuja nimiä vaan puhuu yleisemmällä tasolla personaalisesta passiivista. Johdospassiivilauseita hän pitää aktiivilauseina, vaikka niillä ilmaistaan passiivista toimintaa: Uolevi pyörtyi (mts. 139).

ISK:n (2004 \$1332-1340) mukaan monipersoonaisen passiivin voi muodostaa vain transitiiviverbistä. Predikaattina on verbiliitto, jossa apuverbiin (tulla, joutua, olla) liittyy passiivinen partisiippi (esim. valittu, tutkittava) tai agenttipartisiippilauseke (esim. auton yliajama). Toinen monipersoonaisen passiivin tyyppi ovat automatiiviverbijohdokset (esim. hoitua). Monipersoonaiset passiivit ovat prototyyppisen passiivin kaltaisia: patientti etualaistuu, agentti taka-alaistuu ja verbi intransitiivistuu. ISK:n monipersoonainen passiivikäsite ei sisällä vaatimusta verbinmuodon passiivisuudesta eikä mainintaa persoonaviittauksen epämääräistämisestä.

\subsection{Muutospassiivi}

VISK:n (s.v. muutospassiivi) ja ISK:n (2004 $\$ 1333)$ mukaan muutospassiivi ilmaisee muutoksen tulosta. Rakenne muodostuu tulla- tai joskus joutua-verbistä ja translatiivimuotoisesta partisiipista, esimerkiksi jouduin poliisin yllättämäksi. Passiivisen verbiliiton keskeisenä osana on passiivimuotoinen tai -tulkintainen partisiippi. Agenttipartisiippi (poliisin yllättämäksi) ei sisällä passiivin tunnusta mutta on muilta ominaisuuksiltaan passiivin kaltainen. Verbi kongruoi yleensä edellään olevan subjektin kanssa. Määritelmä on implisiittinen, koska muodoltaan aktiivinen verbi tulkitaan passiiviseksi lauseen passiivitehtävän, patientin etualaistuksen, takia.

ISK:n (2004 $\$ 1333)$ mukaan muutos- ja tilapassiivi implikoivat yleensä ihmistarkoitteisen tekijän tai muun subjektiargumentin ja pakollinen subjektiargumentti on genetiivimuotoinen NP: jouduin sateen yllättämäksi poliisin kuulusteltavaksi. Täten finiittiverbillä on 1. persoona subjektina ja partisiipin tekijä on poliisi, joten kaikki lauseen persoonareferenssit ovat spesifejä. Finiittiverbin subjekti ei ole agentiivinen, mutta syntaktisesti muutospassiivilauseet ovat ymmärrettävissä myös partisiippilausekkeen sisältäviksi aktiivilauseiksi (ISK $2004 \$ 1336$ ).

7. Muutospassiivin tyyppisiä rakenteita on tarkastellut passiiveina myös Kittilä (2000: 295-296). Hänen luokittelussaan muutospassiivi kuuluu epäsuoriin passiiveihin. Niissä subjekti on kokija. 
Muutospassiivilauseet ovat translatiivimuotoisen nominitäydennyksen sisältävien lauseiden kaltaisia. Esimerkiksi mainituilla ISK:n esimerkkilauseilla on sekä rakenteellista että semanttista yhtäläisyyttä muunnelmiensa kanssa: hän tuli riivatuksi, hän tuli hulluksi, hän joutui potilaaksi. Samankaltaisuutta on myös muutospassiivilauseen (hän tuli syrjityksi) ja jopa tuloslauseen (hänestä tuli syrjitty) välillä, sillä partisiippi on niissä passiivissa, patientti etualainen ja syrjijä häivytetty. Näin ollen muutospassiivin kaltainen passiivisuus ulottuu muutospassiivia laajemmalle.

Muutospassiivin passiivisuus on siis näin ollen prototyyppistä passiivisuutta, patientin etualaistamista. Itkonen-Kaila (1974: 212) pitääkin muutospassiivilauseita hyvinä käännösvastineina romaanisten ja germaanisten kielten prototyyppisille passiivilauseille. Koska tekijää ei häivytetä, muutospassiivi ei ole impersonaalinen.

\subsection{Tilapassiivi}

VISK:n (s.v. tilapassiivi) mukaan tilapassiivi koostuu olla-verbistä ja passiivin partisiipista: tapaus on poliisin tutkima, tapaukset ovat poliisin tutkittavina. Aspektuaalisesti tilapassiivi ilmaisee tilaa. ISK (2004 $\$ 1333-1335)$ mainitsee lisäksi, että passiivimuotoinen tai -tulkintainen partisiippi on essiivissä, nominatiivissa tai partitiivissa ja että tilapassiivikin implikoi yleensä ihmistarkoitteisen tekijän tai muun subjektiargumentin.

Sekä tilapassiivi että edellä esitelty muutospassiivi ovat ymmärrettävissä partisiippilausekkeen sisältäviksi aktiivilauseiksi. ISK (2004 $\$ 1325$, ks. myös $\$ 1335)$ toteaa lisäksi, että yksipersoonainen passiivi ja tilapassiivi ovat osittain samanmuotoisia. Lause piirros on tehty 1870 -luvulla on yksipersoonaisen passiivin perfekti tai muutospassiivin preesens. Niiden ero on aspektuaalis-temporaalinen. ${ }^{8}$

ISK:n $(2004 \$ 1336)$ mukaan tilapassiivi on prototyyppisen passiivin kaltainen siksi, että sen patientti on etualaistettu kieliopillinen subjekti. Muita passiivin ominaisuuksia sillä on vaihtelevasti, koska, kuten agenttipartisiipillisesta lauseesta ratkaisu on johtajan ehdottama käy ilmi, tekijää ei ole häivytetty eikä verbi ole aina passiivissa. Lauseessa asia on hyvin hoidettu tekijä on sen sijaan häivytetty ja verbi sisältää passiivin tunnuksen.

Tilapassiivi muistuttaa Helasvuon (2006: 234) kopulapassiivia (esim. Hilkka on viety sairaalaan). Helasvuo ei katso kopulapassiiviin kuuluvaksi sellaisia rakenteita, jotka eivät sisällä passiivimorfeemeja; tällaisia ovat esimerkiksi agenttipartisiipit. Kopulapassiivi on tilapassiivia passiivisempi, koska sillä on useita passiivin ominaisuuksia: passiivimorfeemi, impersonaalisuus ja objektin etualaistus. Kittilä (2000: 296-298) puolestaan kutsuu tilapassiivin kaltaisia rakenteita resultatiivisiksi passiiveiksi.

8. -ttAvA-passiivimorfeemin sisältävät partisiipit vaihtelevat merkitykseltään jo partisiipin sijan mukaan (ks. ISK 2004 \$ 1340). Erot ovat osin tavanomaisia; essiivi ilmaisee tilapäisempää olemista kuin nominatiivi. On myös konstruktiokohtaisia modaalisia eroja: asia on tutkittavana on reaalinen ja aktuaalinen, asia on tutkittava nesessiivinen ja asia on tutkittavissa episteeminen rakenne. Heli Pekkarisen väitöskirja (2011) on kaikinpuolinen selvitys TAVA-partisiipillisistä rakenteista. 


\subsection{Johdospassiivi}

Monissa kielissä refleksiivijohdos on analysoitu passiivimorfeemiksi (ks. Helasvuo 2006: 236; Shibatani 1985: 825-830). ${ }^{9}$ Esimerkiksi ruotsin passiivitunnus $-s$ on entinen refleksiivijohdin (Pettersson 1996: 74). Blevinsin (2003: 502-507) mukaan useissa slaavilaisissa ja romaanisissa kielissä on aidoiksi passiiveiksi kehittyneitä refleksiivisiä verbinmuotoja mutta myös aitoja impersonaalisia refleksiivijohdoksia. Lisäksi on rajatapauksia, kuten espanjan refleksiivi se vende 'myydään' (Comrie 1977: 49). Helasvuo (2006: 239) pitää suomen automatiivisia refleksiivijohdoksia passiivin sukulaisina mutta niistä erillisinä. Seuraavassa tarkastelen lausetyyppiä, jota Isossa suomen kieliopissa (2004 \1344) kutsutaan johdospassiiviksi.

VISK:n (s.v. johdospassiivi) mukaan johdospassiivi ilmaisee, että subjektitarkoitetta kohtaa verbin ilmaisema muutos, esimerkiksi puu kaatui, asiat hoituvat. Verbijohdin on $U$-loppuinen, ja johdospassiiviverbit kuuluvat automatiivisiin verbijohdoksiin. ${ }^{10}$ Kantaverbi on transitiivinen, kuten kaataa tai hoitaa, kantaverbin objektia vastaa johdoksen subjekti ja kantaverbin subjektin voi ilmaista adverbiaalilla: heiltä heidän toimestaan asia hoitui. (Mp.) Täten johdospassiivilause on syntaktisesti aktiivilauseen kaltainen ja se voidaan muodostaa vain transitiiviverbeistä; patientti on etualaistettu.

ISK $(2004 \$ 336)$ luonnehtii johdospassiivia seuraavasti:

- - merkitykseltään automatiivisen johdoksen subjektitarkoitteella on usein patientin piirteitä. - - Kantaverbin ilmaisema teko tai toiminta kuvataan tilanteessa toimimattomana olevan entiteetin kannalta ja siihen ulkoapäin kohdistuvana. - Puhdista tuulilasi sisäpuolelta, ettet häikäisty pahasti ajaessasi vastavaloon.

ISK:n (mp., ks. myös $\$ 1344,1346)$ mukaan johdospassiivi ja yksipersoonainen passiivi ovat merkittävästi samanlaisia, paitsi että johdospassiivi voi olla myös täysin tekijätön: ovi avautui 'joku eläin $\sim$ tuuli $\sim$ sähkösilmä $\sim$ ovikoodi tms. avasi oven $\sim$ ovi avautui itsestään'. Johdospassiivi muistuttaakin yksipersoonaista passiivia, kun "konteksti tai yleistieto kertoo, että tapahtuma on inhimillisen olennon aikaansaama - - Päätalon romaaneista ei yksikään ole kääntynyt edes ruotsiksi, eikä tule kääntymään” (ISK 2004 $\$ 1346)$. Myös seuraavassa esimerkissä (mp.) vain kirjoituksen sisältö johtaa päättelemään, että johdoksella kaatuvat tarkoitetaan ihmisen toimintaa.

(6) Muutenkin Jupperissa puut kaatuvat ihan liiankin tiuhaan tahtiin. Olen kaiholla katsellut tässä meidän mäessä Kalliotien varrella olevan tontin runsasta puustoa, joka varmasti tulee kaadetuksi, kun pihaan on ilmestynyt plakaatti tontille rakennettavasta kolmesta omakotitalosta.

9. Asiasta on käyty keskustelua käyttäen termejä medio, middle ja middle voice (ks. Blevins 2003: 502 alav.; Kittilä 2000: 296-298).

10. ISK:n (2004 \$334) ja Kulonen-Korhosen (1985: 292-293, 298) mukaan automatiiviset verbijohdokset muodostetaan $U$-loppuisilla johtimilla ja ne kuvaavat automaattista (tekijätöntä, itsestään aiheutunutta) tapahtumista. Kulonen-Korhosen (mas. 304) mukaan deverbaalisista U-johdoksista osa on tekijällisiä passiiveja, osa tekijättömiä automatiiveja. 
Esimerkin ensimmäinen lause on impersonaalinen ja muistuttaa yksipersoonaista passiivia. Se häivyttää inhimillistä tekijää, jonka olemassaolon voi kontekstista päätellä. Siihen verrattuna lause trombin iskiessä puut Jupperissa kaatuvat tiuhaan tahtiin on tekijätön. ISK:n (mp.) mukaan sekin on kuitenkin johdospassiivilause, koska automatiivinen aktiivilause sopii kyseisen kieliopin johdospassiivilauseiden joukkoon. ${ }^{11}$

ISK:n (2004 \$1346) mukaan johdospassiivi jättää yksipersoonaista passiivia enemmän tilaa erilaisille aiheutussuhteiden tulkinnoille, kuten sen esittämästä esimerkistä käy ilmi:

(7) Syynä voi olla sekaannus, koska faksissa rekisterinumero oli kirjoitettu puut-

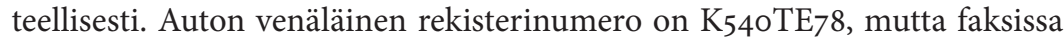
se oli lyhentynyt muotoon K540TE.

Johdospassiivilla vältetään vaikutelma lyhentämisen tahallisuudesta, ja rakenne jättää auki paitsi tekijän identiteetin myös sen, onko tekijä ylipäätään mukana (mp.).

ISK:n (2004\$1346) mukaan johdospassiivilauseen (8a) verbi muovautunut on tekijätön:

(8) a. Vaikka perheen äiti on sisustusarkkitehti, kotia ei ole tehty suunnitelman mukaan - se on vain muovautunut.

Teko näyttää vääjäämättömältä itsestään aiheutumiselta, jolloin tahallisuus, tarkoituksellisuus ja vastuu sumentuvat. Lause voi siis olla automatiivinen olematta impersonaalinen. Tällöin se muistuttaa luonnon tapahtumaa kuvaavaa lausetta, kuten tekemäni muunnelma esimerkin 8a johdospassiivista uudessa kontekstissa osoittaa: Eilen oli maanjäristys. Koti muovautui uusiksi.

Lausetta koti muovautui uusiksi voi analysoida uusissa konteksteissa edelleen. Se saa impersonaalisen tulkinnan, jos tekijä on olemassa ja kysymys on tekijöiden syyntakeisuuden vähättelystä, tekijyyden peittelystä tai teon tuottamuksellisuuden korostamisesta:

b. Teini-ikäiset lapsemme pitivät eilen bileet. Koti muovautui uusiksi.

Impersonaalisuus voi muuttua abstraktiksi, jos prosessi on pitkä ja tekijöitä useita:

c. Lapsiluvun kasvaessa koti vähitellen muovautui uusiksi.

11. Siewierska (2008: 124) käyttää automatiivisista tapauksista termiä antikausatiivi. Esimerkki on englannista (the vase broke), ja siitä puuttuu refleksiivijohdin. Hänen mukaansa lause ei strukturaalisti ole impersonaalinen, koska siinä on subjekti, mutta semanttisesti se on rajatapaus, koska agentti puuttuu. Passiiveiksi ei Siewierska tuollaisia tapauksia katso. Shibatanin (1985: 838-839) mukaan teon voi esittää spontaanisti itsestään tapahtuneena ja siten päästä syyllisyydestä: the vase broke (vrt. I broke the vase). Antikausatiivilla ja passiivilla yhteistä on tekijän demootio. 
Tulos on aiheutunut tuottamuksellisesti yksittäisten tekojen seurauksena, eikä se ole ollut niiden tekijöiden tavoitteena. Aiheuttajana on tällöin kollektiivinen, niin sanottu näkymätön käsi.

Adverbiaalit voivat muuttaa lauseen tekijyyden tulkintaa ja sen subjektin patienttiutta. Lauseessa Ronaldo kaatui tahallaan etualainen subjekti on sekä tekijä että patientti. Lause ei ole siis lainkaan impersonaalinen. Adverbiaali tekee siitä kiistatta aktiivilauseen; ilman sitä se voisi olla johdospassiivilause. Lause Ronaldo uhrautui vahingossa sihteeriksi ei kerro, kenen vahinko oli. Siis uhrasiko joku Ronaldon huomaamattaan vai tuliko Ronaldo uhrautuneeksi tietämättään? Näin ollen lauseen johdospassiivimaisuuden määrittämisessä ei riitä pelkästään verbin ja patienttisubjektin katsominen.

Johdospassiivilauseen impersonaalisuus on omalaatuista, koska sillä voidaan sekä häivyttää tekijää että hämmentää tekijyyttä. Kieliopillisena käsitteenä johdospassiivilause on sumea, koska puheena olevan toiminnan tulkitseminen automaattiseksi riippuu olennaisesti tutkijan yleistiedosta ja kontekstin tulkinnasta. Toinen hankala seikka johdospassiivissa on se, että automatiivijohdin on monesti satunnainen tekijä lauseen semantiikassa. Monet johtamattomatkin verbit kuvaavat automaattista tapahtumista ja saavat etualaistetun patienttisubjektin. Lause avain katosi on joka tapauksessa aktiivinen, vaikka kontekstista voitaisiin päätellä jonkun kadottaneen sen tahallaan. Lauseessa avain hukkui on sen sijaan johdospassiivi, ja se on impersonaalinenkin, jos kontekstista voidaan päätellä jonkun hukuttaneen avaimen tahallaan. Samantapaisia pareja ovat esimerkiksi luento alkoi, luento päättyi ja Kalle syntyi, Kalle kuoli. Johdin on siten vain yksi tekijä rakentamassa lauseen merkitystä tekijyyden, tahallisuuden, automaattisuuden ja impersonaalisuuden osalta. Automaattista tapahtumista kuvaavien lauseiden impersonaalisuus on siten laajempi ilmiö kuin morfologisesti rajattu johdospassiivi. ${ }^{12}$

\subsection{Automatiivijohdos passiivissa}

Kuten on ilmennyt, sekä automatiivijohdos että verbin passiivimuoto häivyttävät tekijää. Ne voivat esiintyä myös samassa verbinmuodossa. Pohdin seuraavaksi verbinmuotojen kaadutaan ja muodostutaan semantiikkaa internetistä löytämieni esimerkkien valossa (esim. 9-12).

(9) Kuinka ollakaan, niin kanta lähti alta pois ja minä kupsahdin kyljelleni. - Minä nousin ylös kuin perhonen ja ei ollut mitään hätää. Olin saanut oppia, miten kaadutaan. Murtuma syntyy, kun kaadutaan ojennetulle kädelle.

Esimerkeissä kaatuja on ihminen, puhuja tai muu tuttu, jonka kokemuksia passiivimuoto yleistää. Lause kun kaadutaan ojennetulle kädelle (esim. 9) ei kerro mitään kaatu-

12. Shibatanin (2006: 234-237) mukaan passiivin sukulainen refleksiivi (middle) on useinkin morfologisesti merkitsemätön, esimerkiksi saksassa aufstehen 'nousta ylös' mutta sich hinsetzen 'istuutua'. Haiman (1985) esittelee saman jaon kutsuen morfologisesti merkitsemättömiä verbejä introverttisiksi ja merkittyjä ekstroverttisiksi. 
misen syistä tai kaatajasta, mutta kaatuja geneeristyy. $U$-johtimen merkitys lauseissa on automaattinen tai refleksiivinen, mutta impersonaalisuus on passiivimorfeemin varassa.

Seuraavat muovautua-verbin esiintymät (esim. 10-12) osoittavat tahallisuuden, automaattisuuden ja refleksiivisyyden monia sävyjä, ja tekijän ja patientin roolit sekoittuvat:

(10) Pitkään ja pysyvään parisuhteeseen muovaudutaan sitten yhdessä ajan myötä.

(11) Olen seurannut, en yllättyneenä, pikemminkin huvittuneena ihmisluonnon perimmäisistä pinttymistä, kuinka ihan jees -rantakunnosta muovaudutaan jumalaiseksi fitnesstähdeksi.

(12) Papiksi muovaudutaan. Osittain tämä formatoituminen tapahtuu tärkeänä opiskeluaikana ja sitä ennen, mutta yleensä suurimmaksi osaksi itse virassa.

Lauseet ovat impersonaalisia peitellessään ja yleistäessään tekijöitä ja patientteja. Passiivimorfeemilla ilmaistu persoonareferenssi on yleistävä ja samastumista tarjoava; lähtökohtana on oma kokemus tai havainto. $U$-johdin kuvaa tekemisen automatiivisrefleksiiviseksi. Esiintyessään samassa verbissä automaattisuuden ja impersonaalisuuden merkitykset ilmenevät eri morfeemien kautta.

\section{Passiivi vai sanajärjestysmuunnos suomen kielen etualaistuksen kieliopillisena keinona?}

Kuten edellä on ilmennyt, prototyyppisen passiivin keskeinen piirre on patientin etualaistus: Bill was hit by John. Aktiivilauseen objektista tulee alkuasemainen subjekti, ja verbi on passiivissa. Tällaista passiivia ei suomessa ole, ja esimerkiksi lausetta Villeä on lyöty Jussin toimesta voi pitää lähinnä omituisena. ${ }^{13}$ Suomessa etualaistaminen tapahtuu sanajärjestystä muuttamalla: Villeä löi Jussi tai Villeä Jussi löi. Itkonen-Kailan (1974) mukaan sanajärjestysmuunnokset ovatkin prototyyppisten passiivilauseiden suosituimpia käännösvastineita. ${ }^{14}$ Lause, jossa objekti on eloton (esim. the table is made by John),

13. Selitys omituisuuteen lienee se, että tällaisen lauseen tekijä ei voi olla yksilö. Sen sijaan esimerkiksi instituutio kävisi hyvin: Vuositasolla laukauksia ammutaan poliisin toimesta 10-20. Asia vaatii lisätutkimusta. Kuiri (2000) katsoo, että tällaisten vierasvaikutteisissa lauseissa ei luontevasti voi olla tekijää, mutta toimeksiantaja käy.

14. Tarkemmin suomen yksipersoonaisten passiivilauseiden kääntämistä ovat tutkineet Riionheimo, Kolehmainen ja Meriläinen (2014). Tutkimus osoittaa, että suomen passiivilauseet on useimmiten käännetty saksaksi subjektillisiksi aktiivilauseiksi (subjektittomia $3 \%$ ), mikä heijastaa saksan ominaisuuksia. Suomen kannalta on kiintoisaa, että $48 \%$ käännösvastineista saa tekijäsubjektin, $28 \%$ patienttisubjektin ja 10 \% ei-inhimillisen tekijäsubjektin. Aktiivisten käännösvastinelauseiden enemmistössä on tekijäsubjekti, passiivilauseissa patienttisubjekti. Kirjoittajat pitävät syynä suomen passiivin henkilötekijäisyyttä. Aktiivilauseiden käännösvastineiden subjekteista 20 \% on indefiniittisiä (man, jemand, Leute) ja $23 \%$ :ssa on referenssiltään spesifi persoonapronomini (enimmäkseen wir). Man esiintyi käännöksissä enemmän kuin alun perin saksaksi kirjoitetuissa teksteissä, mitä pidetään suomen vaikutuksena. Hyvin merkittävä on havainto, ettei yhtäkään aineiston suomen passiivilausetta ole käännetty saksan prototyyppiseksi werden-passiivilauseeksi, jossa agentti ilmaistaan von-rakenteella (mas. 353). Suomen passiivin vastine ei siis ole saksan passiivi, vaan etualaistusta ja impersonaalisuutta ilmaistaan näissä kielissä eri keinoin. (Mas. 346-354.) 
voidaan kääntää luontevasti kahdella erilaisella rakenteella: pöytä on Jussin tekemä tai pöydän teki Jussi. ISK:n (2004 $\$ 1333-1335)$ mukaan agenttipartisiipillinen lause pöytä on Jussin tekemä on tilapassiivilause. Sen ainoa passiiviominaisuus on patientin etualaistus, sillä verbirakenne on aktiivimuodossa. Tosin ISK $(2004 \$ 1313)$ esittää, että tällaisissa tapauksissa verbin muoto on passiivitulkintainen, mikä on hieman epämääräistä.

Tilapassiivin passiivisuus on siis ohutta. Jos pelkkä patientin etulaistus riittää, olisi johdonmukaista pitää muitakin vastaavia aktiivilauseita, kuten Jussia löi Ville ja Jussia Ville löi, ainakin jossain märin passiivisina.

Tilapassiivi ja muut monipersoonaiset passiivit etualaistavat patientin, mutta ilman kvantatiivista tutkimustakin voinee sanoa, että ne eivät useinkaan ole impersonaalisia ja niissä verbi on harvoin passiivissa. Samoin voidaan todeta, ettei monipersoonaisen passiivilauseen patientti ole alkuasemassa, jos informaatiorakenne edellyttää muuta sanajärjestystä (esim. 13-14):

(13) Isän tekemä on esimerkiksi tuo pöytä.

(14) Eilen poliisin yllättämäksi joutui Kalle.

ISK:n (2004) näkemyksen mukaan nämä eivät olisi passiivilauseita, koska niissä ei ole etualaistettua patienttia (ks. mt. $\$ 1332-1340$ ). ${ }^{15}$ Tämäkin osoittaa, että sanajärjestys on ratkaisevin tekijä monipersoonaisten passiivien passiiviuden määrittämisessä.

Kuten tunnettua, lähes mitä tahansa verbin määritteitä voi suomessa tilanteen vaatiessa etualaistaa, niin kuin esimerkit (15-19) osoittavat:

(15) Annalta hukkui lompakko.

(16) Mäntyankeroisen heikentäminä puut kaatuivat leikiten.

(17) Maijan ansiosta puut kaatuivat leikiten.

(18) Meisselillä ikkuna sitten avattiin.

(19) Aikuiseksi Erkki lopulta kasvoi.

Prototyyppinen passiivi (Bill was hit by John) on kiinteäsanajärjestyksisten kielten kieliopillistuma, jolla subjektiksi "muutettu" objekti saadaan lauseen alkuun subjektin kanoniselle paikalle. Sijamerkinnän ansiosta suomessa objekti voi olla objektina lauseen alussa ja subjekti voi olla olematta lauseen alussa sekä transitiivi- että intransitiivilauseessa. Etualaistavan passiivin kaltaista kieliopillisia suhteita muuttavaa rakennetta ei tarvita.

15. Etualaistus on myös lausetyyppikohtaista. Helasvuon ja Huumon (2010: 187) mukaan subjektiargumentin taka-alaistaminen voi toteutua passiivia paremmin muodoltaan aktiivisessa nollapersoonalauseessa. Näin on esimerkiksi eksistentiaalilauseessa, jonka verbin jälkeisellä e-NP:Ilä ei ole agentiivisen ja semanttisesti keskeiseksi hahmottuvan perussubjektin ominaisuuksia, esimerkiksi paikkaa etualassa. 
Shibatani (2006: 245-256) katsoo pragmaattisesti motivoituneessa päluokkajaossa (voice) prototyyppisen aktiivi-passiivi-systeemin ja suora-käänteinen-sanajärjestysmuuntelun samanfunktioisiksi. ${ }^{16}$ Molemmissa aktiivilauseen tekijä väistyy paikaltaan pragmaattisista syistä ja objekti ottaa sen paikan. Passiivissa tapahtuu kieliopillisia muutoksia, inversiossa ei. Suomi on inversiokieli, koska subjekti ja objekti säilyvät sijamerkinnöiltään entisellään. Vain kopulapassiivi (ks. Helasvuo 2006) muistuttaa merkittävässä määrin etualaistavaa passiivia.

Ei liene empiirisesti tutkittu sitä, onko patientin etualaistamisen ja tekijän häivyttämisen välillä keskinäistä riippuvuutta. Voi kuitenkin Comrien (1977) tapaan olettaa, että etualaistaminen on sinänsä riippumatonta tekijän häivyttämisestä; toisin sanoen lauseen tekijän tuntemattomuus tai yhdentekevyys ei vaikuta patientin nostamiseen lauseen alkuun. Kannattaa kuitenkin huomata, että koska passiivilauseen rakenne on subjektin puuttuessa erilainen kuin aktiivilauseen, verbin edessä on vapaa paikka, jonka objekti usein täyttää.

\section{Yhteenveto}

Kuten edellä on ilmennyt, suomen ja muidenkin kielten passiivi- ja impersonaalilauseet ovat semanttisesti ja syntaktisesti moninainen konstruktioiden joukko. Näitä konstruktioita koskevassa yleislingvistisessä tutkimuksessa käsitteiden systematiikka on hajanaista. Impersonaalia on pidetty muun muassa jollain tavoin sekundäärisenä passiivina, ja joillekin tutkijoille taas passiivi on yksi impersonaalien laji. Passiivin ja impersonaalin käsitteellisessä kentässä on pelkistäen sanottuna kaksi keskeistä ulottuvuutta, persoonan häivyttäminen ja objektin etualaistus. Suomen kielen perinteinen passiivi on persoonan häivytyskeino, kun taas esimerkiksi englannin passiivin tehtävä on objektin etualaistus.

Onko suomen perinteinen passiivi siis prototyyppinen etualaistava passiivi? Kysymykseen pitäisi vastata selvästi Setälän (1880), Penttilän (1963), Tuomikosken (1971) ja Shoren (1986) tapaan: suomessa ei ole prototyyppistä etualaistavaa passiivia. Kopulapassiivi (ks. Helasvuo 2006) muistuttaa eniten etualaistavaa passiivia, ja toisaalta Vilkunan (2000) ja Ison suomen kieliopin (2004) passiivimääritelmät korostavat etualaistamista. Kaiken kattavat passiivin määritelmät ovat helposti epäselviä (esim. määritelmät 1 ja 3 s. 117-118). Suomessa objekti - kuten muukin verbin seuralainen - voidaan etualaistaa sekä aktiivi- että passiivilauseen alussa pelkästään sanajärjestystä muuttamalla. Etualaistamisen keinoja ovat myös ISK:n (2004) mainitsemat muutospassiivi ja tilapassiivi, joissa kuitenkin on aktiiviverbi. Lausekohtaista tematisointia voi muunnella myös pragmaattisilla liitepartikkeleilla.

16. Tutkimus esittelee joukon erilaisia kieliä, joiden morfosyntaktiset rakenteet ovat mutkikkaita ja monifunktioisia. Pääluokkajakoon vaikuttavia tekijöitä ovat verbien transitiivisuuden aste, teon tahallisuus ja spontaanisuus (lähes samaa kuin automaattisuus Shibatani 2006: 222-229). Esimerkiksi japanissa on käytössä molemmat systeemit. 
Fennistiikan viime aikojen tutkimus on osoittanut impersonaali-ilmausten keskinäistä sukulaisuutta ja toisaalta niiden sävyeroja ja tehtävien jakoa. Yksipersoonainen passiivi, nollapersoonalause, 2. persoonan avoin käyttö ja johdospassiivi toteuttavat kaikki samaa semanttista funktiota, persoonan häivytystä. Suomen tekijää häivyttävä, niin sanottu perinteinen termi passiivi kannattaa kansainvälisen lingvistisen terminologian valtavirtaa seuraten vaihtaa impersonaaliin. Sitä on usein ehdotettukin, ja näin on tehty viron kielen kuvauksissa (ks. alaviitettä 6). Tutkimuskäytännössä impersonaalien semanttinen samankaltaisuus ja tehtävien jako on jo tunnettu tosiasia, joten kutsuttakoon muitakin impersonaalisia ilmauksia impersonaaleiksi, siis nolla(persoona)impersonaaliksi, 2. persoonan impersonaaliksi ja johdospassiivia automatiiviseksi impersonaaliksi. Näiden rakenteiden nimeäminen impersonaaleiksi ja tätä kautta tapahtuva yhdistäminen on perusteltavissa myös sillä, että näin niiden ero etualaistavaan passiiviin tulee selväksi.

Tutkimushistoriallisesti on huomattava, että fennistiikan passiivitutkimuksessa on vaikuttanut sitkeästi prototyyppisen passiivin malli, joka periytyy kielioppiperinteeltään vaikutusvaltaisisista indoeurooppalaisista kielistä. Passiiveiksi on ehdotettu monenlaisia etualaistavia rakenteita, jolloin passiivista on tullut sekakoosteinen käsite. Passiiveina on pidetty esimerkiksi etualaistavaa tilapassiivia pöytä on isän tekemä ja impersonaalilausetta Pirjon Krouvissa suunniteltiin monta keikkaa, vaikka yhteistä niillä on vain prototyyppisen tekijäsubjektin puuttuminen.

Lingvistiikan suuria kysymyksiä on typologisesti perusteltujen kieliopin kategorioiden siirrettävyys kielestä toiseen. Kieltä olisi kuitenkin kuvattava tekemättä väkivaltaa sen luontaisille ominaisuuksille. Etualaistava passiivi on maailman kielissä yleinen ja kieliopin käsitteenä perusteltu. Suomen kielen etualaistamista olisi sen sijaan hyödyllisempää tutkia suomelle ominaisesta sanajärjestyksen muuntelusta käsin.

\section{Lähteet}

Blevins, James P. 2003: Passives and impersonals. - Journal of Linguistics 39 s. 473-520. https://doi.org/10.1017/Soo22226703002081.

Comrie, Bernard 1977: In defence on spontaneuous demotion. The impersonal passive.

- Peter Cole \& Jerrold M. Saddock (toim.), Syntax and semantics 8. Grammatical relations

s. 47-58. New York: Academic Press.

Erelt, Tiıu - Viks, Ülle - Erelt, Mati - Kasik, Reet - Metslang, Helle - Rajandi, Henno - Ross, Kristiina - SaAri, Henn - Tael, Kaja - Vare, Silvi 1993: Eesti keele grammatika 2. Süntaks. Tallinn: Eesti Teaduste Akadeemia.

Foley, William - VAN VAlin, Robert 1985: Information packaging in the clause. - Tim Shopen (toim.), Language typology and syntactic structure I s. 282-364. Cambridge: Cambridge University Press.

Haiman, John 1985: Natural syntax. Cambridge: Cambridge University Press.

Helasvuo, Marja-Liisa 2006: Passive - personal or impersonal? - Marja-Liisa Helasvuo \& Lyle Campbell (toim.), Grammar from the human perspective. Case, space and person in Finnish s. 233-255. Amsterdam: John Benjamins Publishing Company.

Helasvuo, Marja-Liısa - Huumo, Tuomas 2010: Mikä subjekti on? - Virittäjä 114 
s. 165-195.

Helasvuo, Marja-Liisa - Vilkuna, Maria 2008: Impersonal is personal. Finnish perspectives. - Transactions of the Philological Society 106 s. 216-245. https://doi.org/10.1111/ j.1467-968X.2008.00208.x.

ISK = Hakulinen, Auli - Vilkuna, Maria - Korhonen, Riitta - Koivisto, Vesa - Heinonen, Tarja Riitta - Alho, Irja 2004: Iso suomen kielioppi. Helsinki: Suomalaisen Kirjallisuuden Seura.

It Konen-Kaila, MarJa 1974: Passiivilauseiden suomentamisesta. - Virittäjä 78 s. 210-214. JAHnsson, A.W. 1871: Finska språkets satslära. Helsingfors: Finska Litteratur-sällskapets tryckeri. Jokela, Hanna 2012: Nollapersoonalause suomessa ja virossa. Tutkimus kirjoitetun kielen aineistosta. Turun yliopiston julkaisuja Sarja - Ser. C osa - Tom. 334 Scripta lingua fennica edita. http://urn.fi/URN:ISBN:978-951-29-4912-o.

KangasmaA-Minn, Eeva 1980: Suomen kielen persoonallisesta passiivista. - Sananjalka 22 s. 57-70.

Kit tilä, Seppo 200o: Passiivin prototyypistä. - Anneli Pajunen (toim.), Näkökulmia kielitypologiaan s. 286-312. Helsinki: Suomalaisen Kirjallisuuden Seura.

Kuiri, Kaija 2000: Kielelllistä passiivisuutta. Miksi me mennään? - Kielikello 3/200o s. 13-15.

Kulonen-Korhonen, Ulla 1985: Deverbaalisten U-johdosten semantiikkaa. - Virittäjä 89 S. 290-309.

Laitinen, Lea 2006: Zero person in Finnish. A grammatical resource for construing human reference. - Marja-Liisa Helasvuo \& Lyle Campbell (toim.), Grammar from the human perspective. Case, space and person in Finnish s. 209-231. Amsterdam: John Benjamins Publishing Company.

Larjava ara, Matti 2007: Nykyfennistiikkaa englanniksi. [Arvio teoksesta Marja-Liisa Helasvuo \& Lyle Campbell (toim.): Grammar from the human perspective. Case, space and person in Finnish.] - Sananjalka 49 s. 202-238.

Lauranto, YrJö 2015: Direktiivisyyden rajoja. Suomen kielen vaihtokauppasyntaksia. Helsingin yliopisto. http://urn.fi/URN:ISBN:978-951-51-118o-7.

Linkomies, Edvin 1933: Latinan kielioppi. Jyväskylä: Gummerus.

Löflund, Juhani 1998: Suomen kielen yleiskielen passiivi. Åbo: Åbo Akademis förlag.

Makkonen-Craig, Henna 2005: Toimittajan läsnäolo sanomalehtitekstissä. Näkökulmia suomen kielen dialogisiin passiivilauseisiin. Helsinki: Suomalaisen Kirjallisuuden Seura.

Nuutinen, Olli 1981: Suomea suomeksi 2. Helsinki: Suomalaisen Kirjallisuuden Seura.

Penttilä, Aarni 1957: Suomen kielioppi. Porvoo: WSOY.

1963: Suomen kielioppi. Toinen, tarkistettu painos. Porvoo: WSOY.

Pekkarinen, Heli 2011: Monikasvoinen TAVA-partisiippi. Tutkimus suomen TAVAkäytttökonteksteista ja verbiliittojen kieliopillistumisesta. Helsingin yliopisto: Suomen kielen, suomalais-ugrilaisten ja pohjoismaisten kielten ja kirjallisuuksien laitos. http://urn. fi/URN:ISBN:978-952-10-6965-9.

Pettersson, Gertrud 1996: Svenska språket under sjuhundra år. Lund: Studentlitteratur.

Pä̈̈KKÖNEN, IRMELI 1994: Suomalainen sydämestä. Carl Niclas Keckmanin toiminta suomen kielen kehittäjänä. Helsinki: Suomalaisen Kirjallisuuden Seura.

Riionheimo, Helka - Kolehmainen, Leena - Meriläinen, Lea 2014: Suomen passiivi kontaktissa. Kieltenvälisiä kytköksiä migraatiossa, toisen kielen omaksumisessa ja kääntämisessä. - Virittäjä 118 s. 343-371.

SEtälä, E. N. 1880: Suomen kielen lause-oppi. Oppikirjan koe. Helsinki: K. E. Holm.

— 1891: Suomen kielen lause-oppi. Oppikouluja varten. Kolmas, muutettu laitos. Helsinki: 


\section{K. E. Holm.}

Setälä, E. N. - Nieminen, KaArlo - Ojajärvi, Aulis 1974: Suomen kielen oppikirja. Helsinki: Otava.

Shibatani, Masayoshi 1985: Passive and related constructions. A prototype analysis. - Language 61 s. 821-848. https://doi.org/10.2307/414491.

2006: On the conceptual framework for voice phenomena. - Linguistics 44 s. 217-269. https://doi.org/10.1515/LING.2006.009.

Shibatani, Masayoshi (toim.) 1988: Passive and voice. Typological Studies in Language 16. Amsterdam: John Benjamins.

Shore, Susanna 1986: Onko suomessa passiivia? Helsinki: Suomalaisen Kirjallisuuden Seura.

Siewierska, Anna 2005: Passive constructions. - Martin Haspelmath, Mathew Dryer, David Gill \& Bernard Comrie (toim.), The world atlas of language structures s. 434-437. Oxford: Oxford University Press.

2008: Impersonalization from a subject centered vs. an agent centered perspective. - Transactions of the Philological Society 106 s. 115-137. https://doi.org/10.1111/j.1467968X.2008.00211.X.

Sorjonen, Marja-Leena 2001: Lääkärin ohjeet. - Marja-Leena Sorjonen, Anssi Peräkylä \& Kari Eskola (toim.), Keskustelu lääkärin vastaanotolla s. 89-111. Tampere: Vastapaino.

Suomalainen, Karita 2018: Sinä, konteksti ja monitulkintaisuus. Yksikön 2. persoonan viittaukset arkikeskustelussa. - Virittäjä 122 s. 320-355. https://doi.org/10.23982/vir.63686.

Tuomikoski, Risto 1971: Persoona, tekijä ja henkilö. - Virittäjä 75 s. 146-152.

Uusitupa, Milla 2017: Rajakarjalaismurteiden avoimet persoonaviittaukset. Publications of the University of Eastern Finland. Dissertations in Education, Humanities, and Theology, no 117. http://urn.fi/URN:ISBN:978-952-61-2646-3.

VIlkuna, Maria 2000: Suomen lauseopin perusteet. Toinen, korjattu painos. Helsinki: Edita. VisK = Hakulinen, Auli - Vilkuna, Maria - Korhonen, Rittta - Koivisto, Vesa - Heinonen, Tarja Rittta - Alho, Irja 2004: Iso suomen kielioppi. Määritelmät. Helsinki: Suomalaisen Kirjallisuuden Seura. Verkkoversio. http://scripta. kotus.fi/cgi-bin/visktermit/visktermit.cgi (16.8.2016).

Kirjoittajan yhteystiedot (address):

etunimi.sukunimi@gmail.com

Kirjoittaja on suomen kielen yliopistonlehtori emeritus Helsingin yliopistossa. 